\title{
Formation of apatitic calcium phosphates in a Na-K-phosphate solution of pH 7.4
}

\author{
A. C. TAS $^{1, * \dagger}$, F. ALDINGER ${ }^{2}$ \\ ${ }^{1}$ School of Materials Science and Engineering, Clemson University, Clemson, \\ SC 29634, USA \\ E-mail:c_tas@hotmail.com \\ ${ }^{2}$ Pulvermetallurgisches Laboratorium, Max-Planck-Institut fuer Metallforschung, \\ D-70569 Stuttgart, Germany
}

Poorly crystalline, apatitic calcium phosphate powders have been synthesized by slowly adding a $\mathrm{Na}$ - and K-containing reference phosphate solution with a $\mathrm{pH}$ value of 7.4 to an aqueous calcium nitrate solution at $37^{\circ} \mathrm{C}$. Nano-particulated apatitic powders obtained were shown to contain small amounts of $\mathrm{Na}$ and $\mathrm{K}$, which render them more similar in chemical composition to that of the bone mineral. Precipitated and dried powders were found to exhibit self-hardening cement properties when kneaded in a mortar with a sodium citrate- and sodium phosphate-containing starter solution. The same phosphate solution used in powder synthesis was found to be able to partially convert natural, white and translucent marble pieces of calcite $\left(\mathrm{CaCO}_{3}\right)$ into calcium-deficient hydroxyapatite upon aging the samples in that solution for 3 days at $60^{\circ} \mathrm{C}$. Sample characterization was performed by using scanning electron microscopy, X-ray diffraction, Fourier-transform infrared spectroscopy, inductively-coupled plasma atomic emission spectroscopy, and simultaneous thermogravimetry and differential thermal analysis.

(C) 2005 Springer Science + Business Media, Inc.

\section{Introduction}

Synthetic bone substitutes, which will be successfully used as implant materials in orthopedic surgery, are mainly required to be as similar as possible to the mineralized part of the host bones in terms of chemical composition, structure and crystallinity. Synthetic, crystalline and stoichiometric hydroxyapatite $\left(\mathrm{HA}: \mathrm{Ca}_{10}\left(\mathrm{PO}_{4}\right)_{6}(\mathrm{OH})_{2}\right)$ with a $\mathrm{Ca} / \mathrm{P}$ molar ratio in the vicinity of 1.67 , and highly crystalline beta-tricalcium phosphate (TCP: $\left.\mathrm{Ca}_{3}\left(\mathrm{PO}_{4}\right)_{2}\right)$ are commonly [1-10] conceived or used implant materials which are nevertheless not perfectly similar to the host bones. While the former of these bioceramics does not have a significant in vivo resorbability to take part in the remodeling of the natural bone unless the ceramic is porous enough, the latter simply undergoes quite a rapid (passive) dissolution at the low $\mathrm{pH}$ value (i.e., 4.2 to 4.3 ) of the osteoclastic environment [11].

Natural bones are long known to be poorly crystallized materials [12] with quite a complex chemistry, and "the in vivo hard tissue mineralization proceeds through the initial deposition of an amorphous (noncrystalline) calcium phosphate solid phase, followed by the subsequent transformation of the major part of this solid phase into nanocrystals of apatite [13]." Moreover, such biomineralization of calcium phosphates takes place "within a matrix of collagen fibrils, gylcoproteins (proteins with sugar side chains) and many other types of proteins [14]."

Since the synthetic bone substitute implant (either as a putty, paste, block or granule) would be placed by the surgeon in immediate contact with the surface of the natural bone (which will grow, resorb or remodel itself in response to the implant), the ideal implant itself must be able to fully participate in these processes. The key to this participation lies in the chemical and physical similarity between the two.

In the course of developing simpler and robust manufacturing processes for the wet-chemical synthesis of nanosize, poorly crystalline calcium-deficient hydroxyapatite (with a nominal formula of $\mathrm{Ca}_{9}$ $\left.\left(\mathrm{HPO}_{4}\right)\left(\mathrm{PO}_{4}\right)_{5} \mathrm{OH}\right)$ bioceramics, we have found that the use of a simple Na-K-phosphate reference solution, as the synthesis medium, may simultaneously serve three purposes; namely, (1) to provide a neutral $\mathrm{pH}$ medium during synthesis, (2) to supply $\mathrm{Na}^{+}$and $\mathrm{K}^{+}$ ions which are expected to be chemically incorporated into the precipitates, and (3) to serve as the only source for phosphate ions during the synthesis runs. The

*Author to whom all correspondence should be addressed.

${ }^{\dagger}$ Formerly, Visiting Professor at Max-Planck-Institut fuer Metallforschung, Stuttgart, Germany. 
mineral portion of human bones are known to contain [15] a biologically significant amount of $\mathrm{Na}^{+}$and $\mathrm{K}^{+}$ ions (>0.7 wt\%), as well as carbonate ions. Doping of the monovalent $\mathrm{Na}$ and $\mathrm{K}$ at the divalent $\mathrm{Ca}$-sites of CDHA may lead to the formation of vacancies at OHsites, and these altogether would render the material to be more prone to $\mathrm{CO}_{3}^{2-}$ substitutions, both at the $\mathrm{OH}^{-}$and $\mathrm{HPO}_{4}$-sites. CDHA-like precursors obtained in wet-chemical synthesis routes may either convert themselves, upon high temperature calcination, into HA powders or TCP powders (or biphasic mixtures [16] of the two), mainly depending on the $\mathrm{Ca} / \mathrm{P}$ molar ratio adjustment (from 1.8 to 1.5 , respectively) in the synthesis reactors. In this study, we report the use of a simple Na-K-phosphate solution in preparing $\mathrm{Na}$ - and $\mathrm{K}$-doped, carbonated apatitic calcium phosphates in different forms, including apatitic powders, self-setting cements and coating layers on natural marble.

\section{Experimental procedure}

\subsection{Na-K-phosphate solution preparation}

Phosphate solutions with a $\mathrm{pH}$ value of 7.45 (at $21^{\circ} \mathrm{C}$ ) can be easily prepared [17], for instance, by dissolving $0.008695 \mathrm{~mol} / \mathrm{kg}$ of potassium di-hydrogen phosphate, $\mathrm{KH}_{2} \mathrm{PO}_{4}$ ( $>99 \%$ pure, Merck KGaA, Darmstadt, Germany) and $0.03043 \mathrm{~mol} / \mathrm{kg}$ di-sodium hydrogen phosphate $\mathrm{Na}_{2} \mathrm{HPO}_{4}$ (>99\% pure, Merck) in distilled water. For a typical Na-K-phosphate solution preparation, $0.59 \mathrm{~g}$ of $\mathrm{KH}_{2} \mathrm{PO}_{4}$ and $2.152 \mathrm{~g}$ of $\mathrm{Na}_{2} \mathrm{HPO}_{4}$ salts were weighed and then dissolved, respectively, in 500 $\mathrm{mL}$ of distilled water. This brings the proportional molar ratios of $\mathrm{K}, \mathrm{Na}$ and $\mathrm{P}$ in half a liter of the solution to 0.0043:0.0303:0.0195 [17]. $\mathrm{Ca}\left(\mathrm{NO}_{3}\right)_{2} \cdot 4 \mathrm{H}_{2} \mathrm{O}(>99 \%$ pure, Merck) aqueous stock solutions $(0.80 \mathrm{M})$ were used as the Ca-source during all the powder preparation runs.

\subsection{Apatitic powder synthesis}

For the synthesis of poorly-crystalline apatitic powders, a $43.75 \mathrm{~mL}$ aliquot of the Ca-nitrate stock solution (i.e. $0.035 \mathrm{~mol} \mathrm{Ca}^{2+}$ ) was placed into a clean glass beaker of $2 \mathrm{~L}$-capacity, together with $750 \mathrm{~mL}$ of distilled water. The solution ( $\mathrm{pH}=5.6$ to 5.7 at $37^{\circ} \mathrm{C}$ ) was vigorously stirred for $5 \mathrm{~min}$ at $37^{\circ} \mathrm{C}$, while the beaker was kept in a thermostated ethylene glycol (>99\% pure, Merck) bath. The $\mathrm{pH}$ value of this solution was raised to around $9.7 \pm 0.1\left(\right.$ at $\left.37^{\circ} \mathrm{C}\right)$ by adding $2 \mathrm{~mL}$ of concentrated $\mathrm{NH}_{4} \mathrm{OH}$ (>98\% pure, Merck). $500 \mathrm{~mL}$ of the abovementioned phosphate solution (at $37 \pm 0.5^{\circ} \mathrm{C}$ ) was then slowly fed (at the rate of $5 \mathrm{~mL} / \mathrm{min}$ ) into the continuously stirred and $\mathrm{pH}$-monitored Ca-nitrate beaker, by using a liquid pump. The overall $\mathrm{Ca} / \mathrm{P}$ molar ratio in the reaction beaker had been intentionally adjusted to around 1.795 in the above example of synthesizing apatitic powders. Following the completion of phosphate solution addition into the Ca-nitrate solution, the resultant opaque solution was stirred with a magnetic fish at $37 \pm 0.5^{\circ} \mathrm{C}$ for $6 \mathrm{~h}$, and then left overnight $(14 \mathrm{~h})$ at $21 \pm 1{ }^{\circ} \mathrm{C}$ without stirring. $\mathrm{pH}$ value was observed to remain constant at around 7.1 even at the end of this period of aging at room temperature.
Precipitates were recovered from the mother solution(s) by filtration and washed three times with deionized water of a volume of 4 liters. Powders were dried overnight at $90^{\circ} \mathrm{C}$ in a stagnant air oven. Dried powders were first lightly ground by hand using an agate mortar/pestle, and finally calcined (to monitor their sintering behavior) isothermally in a stagnant air atmosphere box furnace, in Pt crucibles as loose powders, over the temperature range of $300^{\circ}$ to $1000^{\circ} \mathrm{C}$. Each calcination batch of powders was heated to the specified temperature at the rate of $5{ }^{\circ} \mathrm{C} / \mathrm{min}$, annealed at this temperature for $90 \mathrm{~min}$, and then cooled to room temperature in the shut-off furnace.

\subsection{Cement testing}

Self-setting/hardening cement behaviour of precipitated apatite powders were tested by using a special starter solution. The starter solution (of a $\mathrm{pH}$ value of 11.5) was prepared [18], prior to its use, by dissolving $2.00 \mathrm{~g}_{\text {of }} \mathrm{C}_{6} \mathrm{H}_{5} \mathrm{Na}_{3} \mathrm{O}_{7} \cdot 2 \mathrm{H}_{2} \mathrm{O}$ (>99\%, Merck) and $2.00 \mathrm{~g}$ of $\mathrm{Na}_{3} \mathrm{PO}_{4} \cdot 12 \mathrm{H}_{2} \mathrm{O}$ (>99\%, Merck), respectively, in $90 \mathrm{~mL}$ of deionized water at room temperature. A $1.00 \mathrm{~g}$ portion of the apatitic powders was mixed in an agate mortar for about 1 minute with an agate pestle together with $0.5 \mathrm{~mL}$ of the starter solution, followed by placing (by a gloved-hand) the formed paste into a stainless steel mold of $1 \mathrm{~cm}$ deep with a diameter of $0.65 \mathrm{~cm}$ diameter. Cylindrical cement samples were thus formed and they were stored under ambient conditions for $1 \mathrm{~h}$ prior to testing. Cements were loaded under compression until failure (Instron 5544) at a crosshead speed of $1 \mathrm{~mm} / \mathrm{min}$, with a $1.5 \mathrm{kN}$ load cell, to determine compressive strength.

\subsection{Conversion of $\mathrm{CaCO}_{3}$ (Calcite) into calcium-deficient apatite in phosphate solutions}

Calcite (>99\%, Merck) powders (2.4 g), as well as white, translucent natural calcite marble (Stuttgart, Germany) cubes $(1 \times 1 \times 1 \mathrm{~cm}$, each weighing about $2.45 \pm 0.05 \mathrm{~g}$ ) were separately placed in $50 \mathrm{~mL}$ of the above-mentioned phosphate solutions contained in $100 \mathrm{~mL}$-capacity, tightly sealed glass bottles. Calcite powder and calcite marble samples were checked by XRD to strictly confirm the rhombohedral $\mathrm{CaCO}_{3}$ (ICDD PDF 83-1762 or 83-0577 [19]) pattern, prior to their use in these experiments. Bottles were kept in a constant temperature oven at temperatures of $37^{\circ}$, $60^{\circ}$ and $90^{\circ} \mathrm{C}$ for $72 \mathrm{~h}$. Following aging at different temperatures for 3 days, the samples were washed with deionized water and dried at $90^{\circ} \mathrm{C}$ for $48 \mathrm{~h}$.

\subsection{Sample characterization}

The phase constitution of the samples was analyzed, as a function of temperature (on isothermally calcined samples), by using a powder X-ray diffractometer (D-5000, Siemens GmbH, Karlsruhe, Germany) with monochromated $\mathrm{CuK}_{\alpha 1}$ radiation $(40 \mathrm{kV}$, $30 \mathrm{~mA})$. XRD data on marble cubes soaked in 
Na-K-phosphate solution of $\mathrm{pH} 7.4$ were gathered by properly mounting those small cubes in the sample holder of X-ray diffractometer. Pyrolysis of accuratelyweighed $150 \mathrm{mg}$ portions of ground samples were monitored by simultaneous differential thermal and thermogravimetric analysis (STA501, Baehr GmbH, Bremen, Germany) in an air atmosphere at the heating rate of $5^{\circ} \mathrm{C} / \mathrm{min}$. $\mathrm{Al}_{2} \mathrm{O}_{3}$ was used as the reference material in all the TG/DTA runs. FT-IR analyses of the samples were performed (IFS 66, Bruker GmbH, Karlsruhe, Germany) after mixing them (1 wt\%) with dry $\mathrm{KBr}$ to form the pellets used in these analyses. ICP-AES analyses were performed to obtain the quantitative elemental $(\mathrm{Ca}, \mathrm{P}, \mathrm{Na}$ and $\mathrm{K})$ information (JY-70Plus, Jobin Yvon S.A., Longjumeau, France) on the precipitated powder samples, after they were dissolved in acid solutions. Morphological features of samples were studied by scanning electron microscopy (DSM 982-Gemini, Zeiss GmbH, Oberkochen, Germany), without coating the samples.

\section{Results and discussion}

\subsection{Apatitic powders}

Fig. 1(a) and (b) show, respectively, the XRD diagram and the SEM morphology of the poorly-crystalline apatitic powders obtained after the slow addition of phosphate solution to Ca-nitrate solution at $37^{\circ} \mathrm{C}$, as described above. Powder consisted of heavily agglomerated, but nanosize particles.

These powders, which possess a $\mathrm{Ca} / \mathrm{P}$ molar ratio of $1.64 \pm 0.02$, a Na content of $0.24 \pm 0.04$, and K of $0.11 \pm 0.03 \mathrm{wt} \%$ (as determined by ICP-AES analysis), were also found to exhibit self-hardening cement properties when $1.0 \mathrm{~g}$ of those were mixed with an agate pestle for about 1 minute in an agate mortar together with $0.5 \mathrm{~mL}$ of the Na-citrate $+\mathrm{Na}$-phosphate starter solution, at the liquid-to-powder ratio of 0.5 . The cylindrical cement specimens (manually consolidated in a steel die) were measured to have a compressive strength of $15 \pm 3 \mathrm{MPa}$. This value is about one third of the compressive strengths of the commercially available $\alpha-\mathrm{Ca}_{3}\left(\mathrm{PO}_{4}\right)_{2}$ or $\mathrm{Ca}_{4}\left(\mathrm{PO}_{4}\right)_{2} \mathrm{O}$-containing calcium phosphate cements, such as Calcibon ${ }^{\circledR}$ or Norian SRS ${ }^{\circledR}$, respectively.

The XRD chart (Fig. 2(a)) of the cement body (after crushing it into a fine powder in an agate mortar) showed that the final product is still a poorly-crystalline, carbonated apatitic material, which is similar to the mineralized portion of natural bones. SEM micrographs of the self-set cylinders formed in the steel mold revealed the presence of platelets of calcium-deficient hydroxyapatite (CDHA), which are quite typical of apatitic calcium phosphate cements, Fig. 2(b). The rapid (within the first 10 minutes following the addition of the starter solution) formation of these interlocked platelets of CDHA gives the porous cement body its mechanical strength and stability [20-22].

FT-IR spectra of these hardened cement samples showed (Fig. 2(c)) that these were actually carbonatedapatite samples. Characteristic carbonate $\left(\mathrm{CO}_{3}^{2-}\right)$ bands are labeled in Fig. 2(c), and the band at around

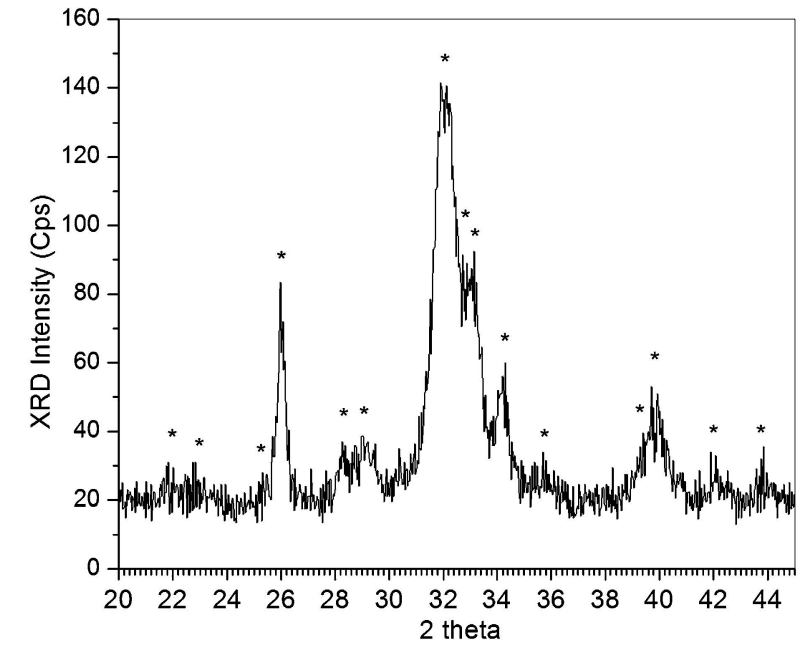

(a)

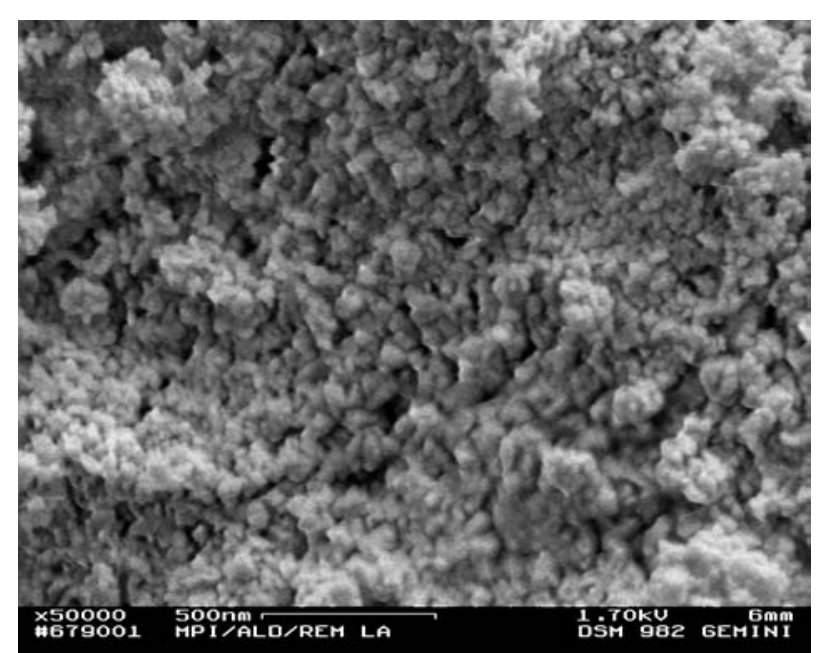

(b)

Figure 1 (a) XRD plot of poorly-crystalline apatitic powders (dried at $90^{\circ} \mathrm{C}$ ); $*$ indicates the peak positions of Ca-hydroxyapatite (ICDD PDF 09-432). (b) SEM micrograph of poorly-crystalline apatitic powders (dried at $90^{\circ} \mathrm{C}$ ).

$3571 \mathrm{~cm}^{-1}$ indicated that the hydroxyl ions are also present in those CDHA platelets, which form the cement samples. All the other bands in Fig. 2(c) were typical of the apatitic calcium phosphates [23].

It has been quite a versatile route to isothermally heat the precipitated calcium phosphate powders over a specified temperature interval, and then monitor the phase evolution and crystallization/calcination behavior of those samples via XRD, FTIR and TG/DTA analysis, to determine the exact nature of the precursors. To this purpose, Fig. 3(a) depicts the XRD traces, as a function of increasing isothermal heat temperature, for apatitic precursor powders mentioned in Fig. 1, while the FT-IR and TG/DTA data are given in Fig. 3(b) and (c), respectively.

Apatitic precursors were found to be still poor in crystallinity even after heating at $500^{\circ} \mathrm{C}$ in air for $90 \mathrm{~min}$. However, upon heating at $850^{\circ} \mathrm{C}$, the hydroxyapatite phase crystallized. Samples heated at $1000^{\circ} \mathrm{C}$ did not decompose into $\beta$-TCP $\left(\beta-\mathrm{Ca}_{3}\left(\mathrm{PO}_{4}\right)_{2}\right)$. XRD traces did also not show any $\mathrm{CaO}$ as an impurity phase, and if $\mathrm{CaO}$ was present its strongest peak (ICDD PDF 48-1467 for 


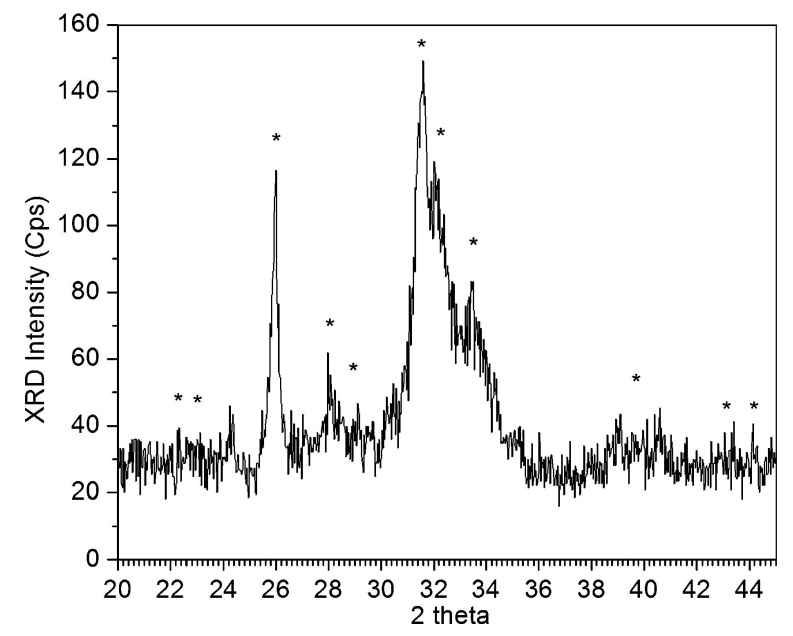

(a)

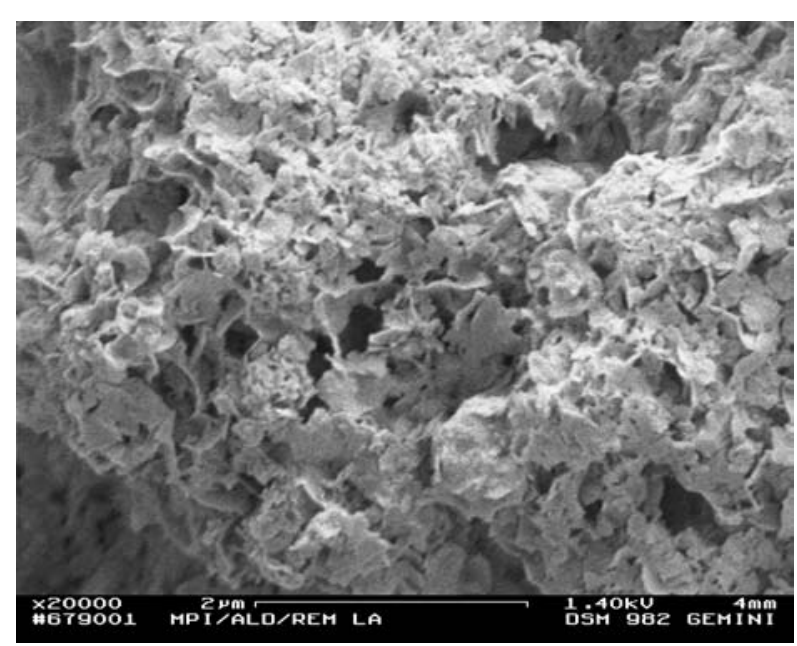

(b)

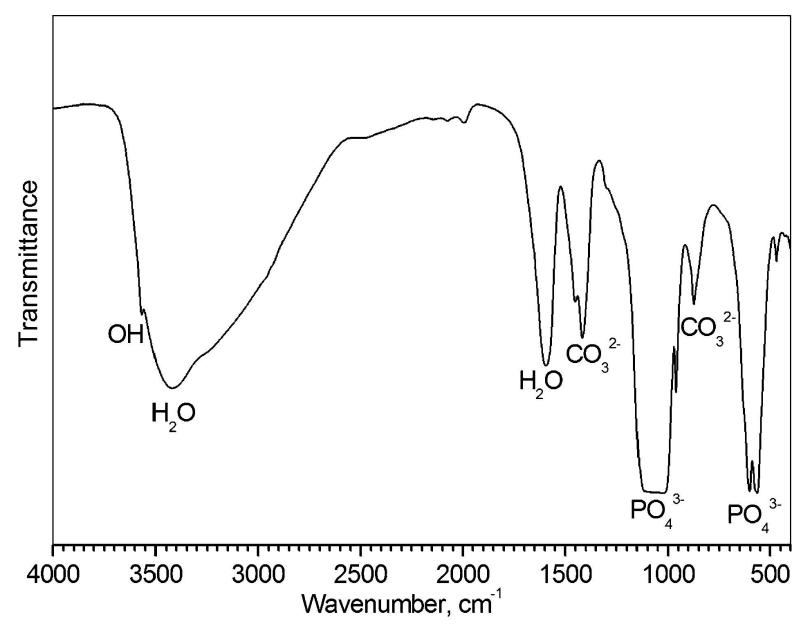

(c)

Figure 2 (a) XRD plot of self-setting cement body prepared by using the powders of Fig. 1; * indicates the peak positions of Ca-hydroxyapatite. (b) SEM micrograph showing the cement body consisting of calciumdeficient hydroxyapatite platelets. (c) FT-IR plot of cement bodies obtained by using the powders depicted in Fig. 1 .

$\mathrm{CaO}$ ) would have been found at around $37.4^{\circ} 2 \theta$. On the other hand, the presence or absence of rhombohedral $\mathrm{CaCO}_{3}$ (Calcite, ICDD PDF 5-586) cannot easily be detected from XRD data since its strongest peaks do overlap with the 210 and 212 reflections of hydroxyapatite [24]. Orthorhombic Aragonite, the high-pressure form

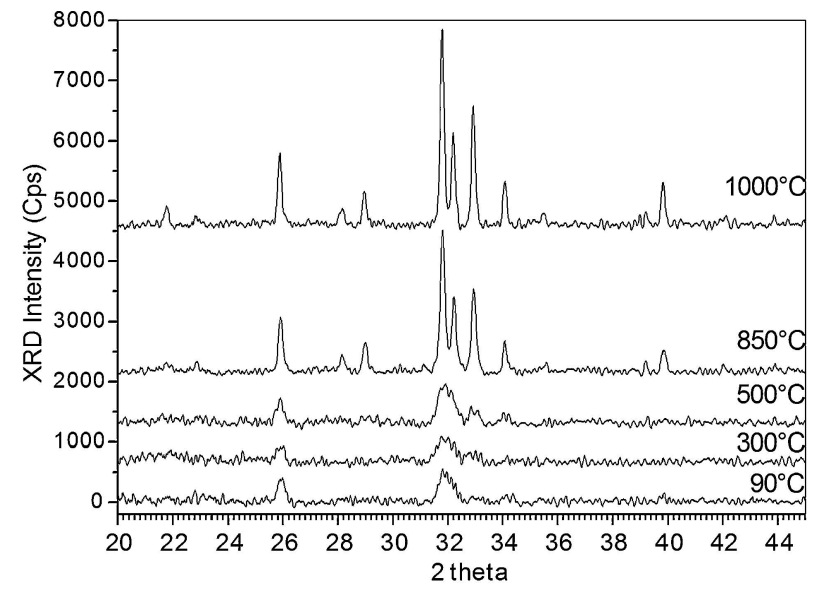

(a)

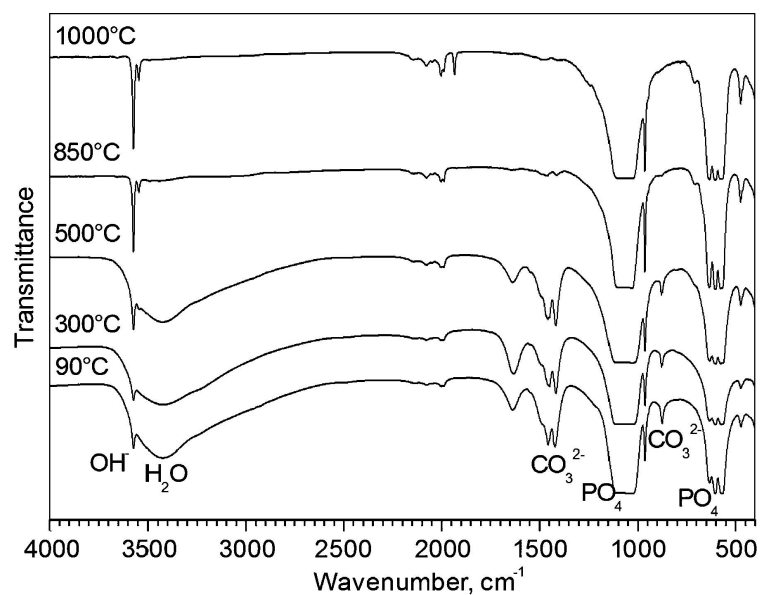

(b)

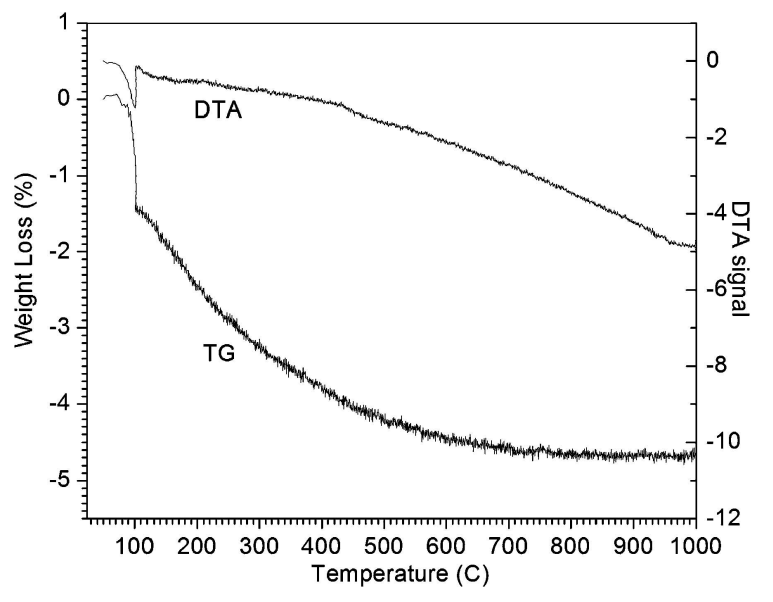

(c)

Figure 3 (a) XRD traces of apatitic precursors as a function of calcination temperature (all traces show single-phase apatite). (b) FT-IR traces of apatitic powder precursors as a function of temperature. (c) TG/DTA plot of the apatitic precursor powders.

of $\mathrm{CaCO}_{3}$ (ICDD PDF 41-1475), was not present in the samples, since in that case its strongest peak would be located at $26.2^{\circ} 2 \theta$. Lattice parameters of the hexagonal (space group $\mathrm{P}_{3} / \mathrm{m}$ ) hydroxyapatite powders calcined at $1000^{\circ} \mathrm{C}$ were found to be $\mathrm{a}=9.401, \mathrm{c}=6.869 \AA$. These experimental parameters, when compared with those of pure $\mathrm{HA}(\mathrm{a}=9.424, \mathrm{c}=6.876 \AA$ [25]), pointed to a shrinkage in the unit cell volume, which is expected in the case of Na-substitutions at $\mathrm{Ca}$-sites. 
FT-IR traces of the apatitic precursors as a function of increasing calcination temperature are given in Fig. 3(b) below. At all temperatures, the data of Fig. 3(b) contained the bands at 3571 and $636 \mathrm{~cm}^{-1}$, corresponding to the $\mathrm{OH}^{-}$stretching and bending vibrations, respectively [26]. $\mathrm{PO}_{4}$ bands were recorded at $470\left(v_{2}\right), 570$ and $603\left(v_{4}\right), 962\left(v_{1}\right), 1045$ and $1096\left(v_{3}\right) \mathrm{cm}^{-1}$, and the group of bands around $2000 \mathrm{~cm}^{-1}$ are also assignable [27] to $\mathrm{PO}_{4}^{3-}$. Carbonate ion absorption peaks were observed at around 1470-1420 and $875 \mathrm{~cm}^{-1}$, in samples heated at low temperatures, i.e., $90^{\circ}$ to $700^{\circ} \mathrm{C}$. The source of carbonate ions in the precursor powders was just the $\mathrm{CO}_{2}$ dissolved (from the air) in the distilled water, which was used during the synthesis runs. It is known that carbonate ions present in precipitated apatitic calcium phosphate powders volatilize upon heating at $T \geq 700{ }^{\circ} \mathrm{C}$ [26]. Adsorption and desorption of water (hydration and dehydration) can be easily monitored by IR, since adsorbed $\mathrm{H}_{2} \mathrm{O}$ gives rise to a typical deformation band [27] around $1640 \mathrm{~cm}^{-1}$, and this was also observed in the data of Fig. 3(b) for the precipitated powders calcined over the temperature range of $90^{\circ}$ to $500^{\circ} \mathrm{C}$. However, the IR spectra given in Fig. 3(b) do coincide well with the hydoxyapatite spectra given in literature [28-32]. The observation of two close but separate IR bands (with increasing temperature) over the range of 3560 to $3650 \mathrm{~cm}^{-1}$ would require further attention, and it is known [33] that, for instance, the IR spectra of $\mathrm{Ca}(\mathrm{OH})_{2}$ would display a strong and sharp $\mathrm{O}-\mathrm{H}$ stretching peak at $3640 \mathrm{~cm}^{-1}$. The presence of two distinct bands over this range may suggest the possibility of a slight $\mathrm{Ca}$-excess (i.e., over the $\mathrm{Ca} / \mathrm{P}=1.67$ stoichiometry of apatite), although such an excess could not be confirmed by our ICP analyses.

TG/DTA analysis performed on the apatitic precursors revealed, as shown in Fig. 3(c), less than 5 wt\% weight loss upon heating them from room temperature to $1000{ }^{\circ} \mathrm{C}$. The initial weight loss of around $1.5 \%$ coincided well with the endothermic event seen (90 to $120^{\circ} \mathrm{C}$ ) in the DTA trace, and this corresponded to the removal of water from the precursors.

SEM photomicrographs given in Fig. 4 display the rapid densification/sintering behavior of the apatitic precursors after heating those at the indicated temperatures for $90 \mathrm{~min}$ as loose powder bodies placed in flat crucibles. Nanosize calcium phosphate particles started to form necks with one another at around $850{ }^{\circ} \mathrm{C}$, and when they were heated to $1000^{\circ} \mathrm{C}$, bonding were

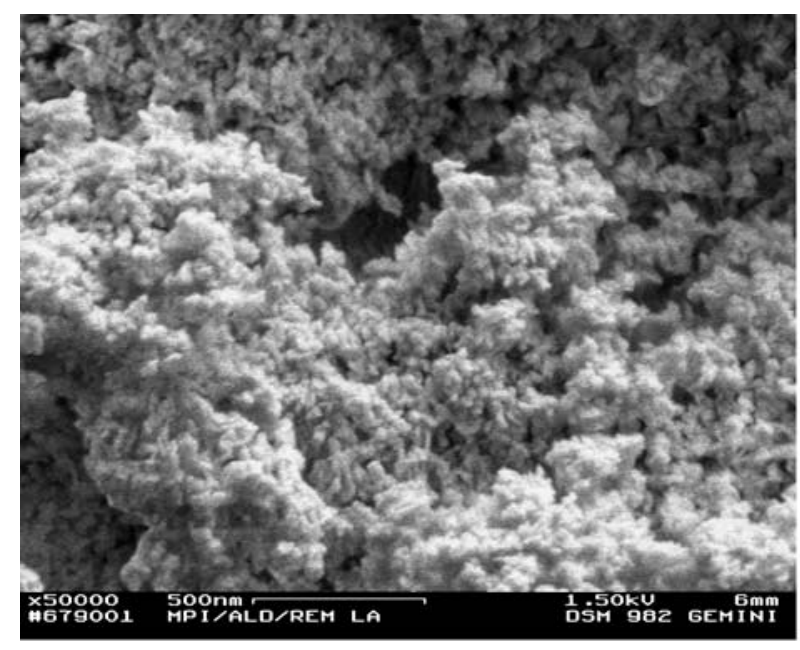

(a)

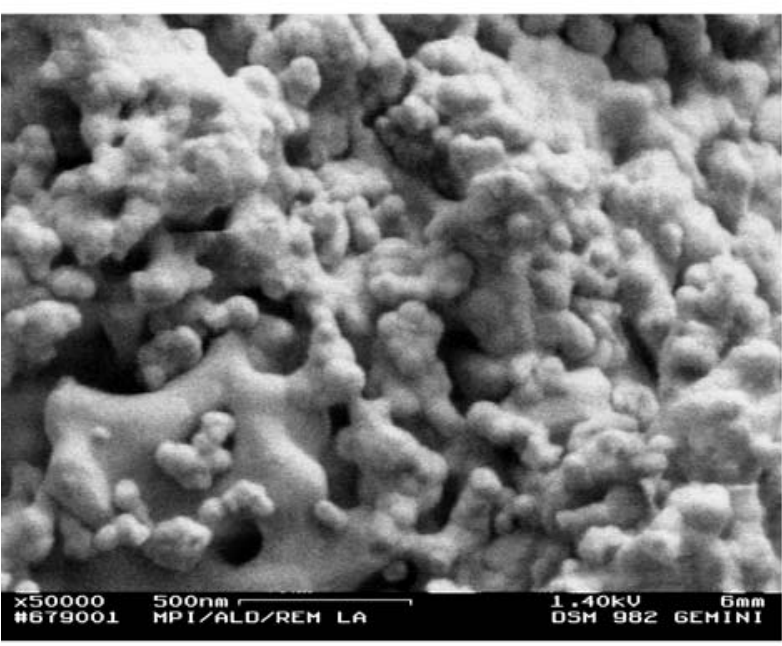

(c)

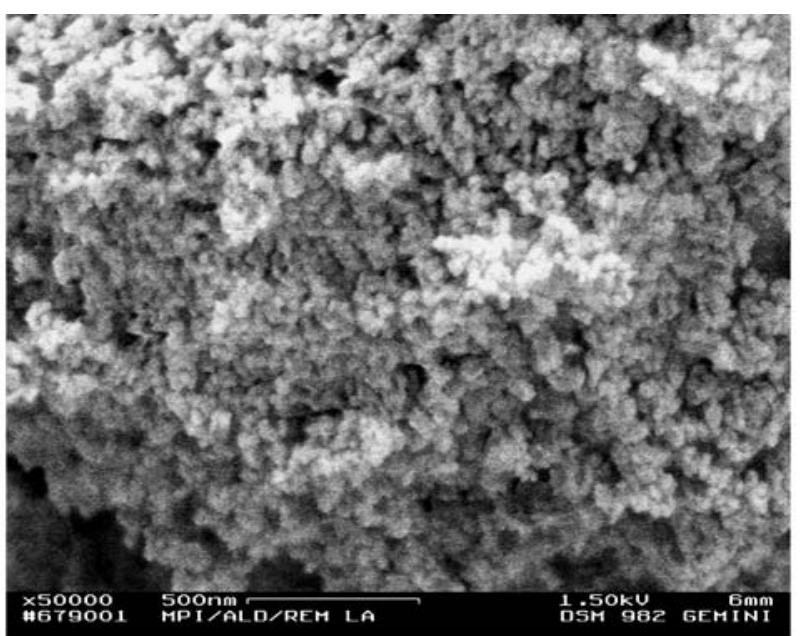

(b)

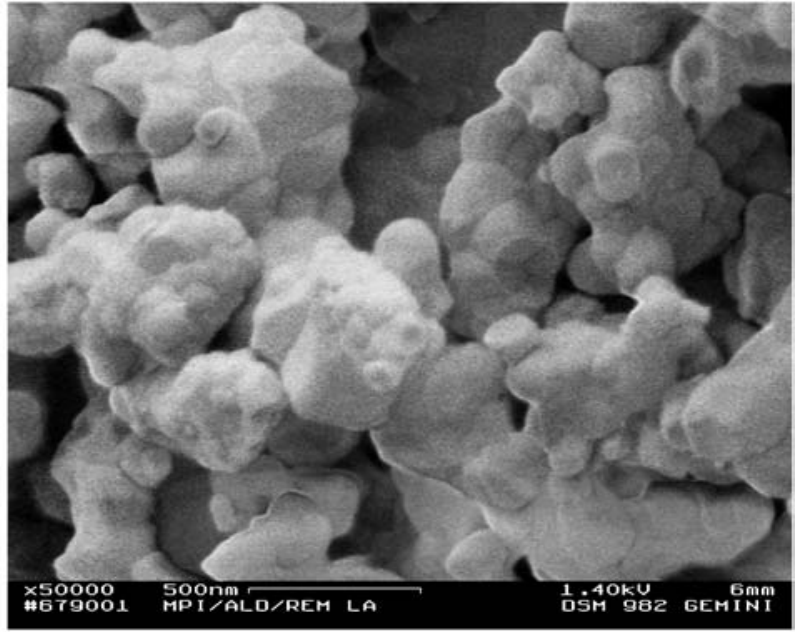

(d)

Figure 4 SEM micrographs of apatitic precursors heated at different temperatures for $1.5 \mathrm{~h}$ : (a) $300^{\circ} \mathrm{C}$, (b) $500^{\circ} \mathrm{C}$, (c) $850^{\circ} \mathrm{C}$, and (d) $1000^{\circ} \mathrm{C}$. 
observed to form among the individual particles. In case of compacting these powders prior to their heating, it should be obvious that these powders would have sintered well even below $1000^{\circ} \mathrm{C}$. For the preparation of low-mechanical strength, but porous apatitic bioceramics in the shape of granules (for using them in nonload bearing, trabecular bone applications), it would just be enough to slightly (using a packing pressure $<2-3 \mathrm{MPa}$ ) force these powders into any desired bulk shape and then calcine them, e.g., at $900{ }^{\circ} \mathrm{C}$ for just a short 90 min.

The powder synthesis procedure reported here may be regarded as a simple and robust alternative to more tedious wet-chemical methods described previously. Peters and Epple [34], for instance, reported the use of Ca-nitrate and $\mathrm{KH}_{2} \mathrm{PO}_{4}$ solutions for the controlled synthesis/crystallization of apatitic powders, but the procedure described there was not able to produce powders in large quantities. Moreover, the use of Soerensen's buffer $\left(5.26 \mathrm{~g} \mathrm{KH}_{2} \mathrm{PO}_{4}+8.65 \mathrm{~g} \mathrm{Na}_{2} \mathrm{HPO}_{4}+\right.$ $1000 \mathrm{~mL} \mathrm{H}_{2} \mathrm{O}$ ) or $0.5 \mathrm{M}$ phosphate buffer (39.749 $\mathrm{g}$ $\mathrm{Na}_{2} \mathrm{HPO}_{4}+14.397 \mathrm{~g} \mathrm{NaH}_{2} \mathrm{PO}_{4}+800 \mathrm{~mL} \mathrm{H}_{2} \mathrm{O}$ ) may further increase the yield of the synthesis procedure described here in this report, which will be tested in our following studies for its influence on the powder morphology and chemistry.

\subsection{Conversion of $\mathrm{CaCO}_{3}$ into $\mathrm{CDHA}$ in $\mathrm{Na}$-K-phosphate solutions}

$\mathrm{CaCO}_{3}$ powders and translucent, calcitic marble cubes soaked in the Na-K-phosphate solutions at $37^{\circ} \mathrm{C}$ for 3 days did not form any calcium phosphate phases on their surfaces, as deduced from the XRD and SEM investigations of those. However, calcite samples (both powders and marble cubes) soaked in the same solutions for 3 days at $60^{\circ}$ and $90^{\circ} \mathrm{C}$ extensively formed calcium-deficient-hdyroxyapatite platelets on their surfaces. XRD data given in Fig. 5 showed that calcite powders (ICDD PDF 5-586) even lost a significant portion of their crystallinity after soaking at $60^{\circ} \mathrm{C}$, and partially converted into CDHA. Marble cubes, which had the

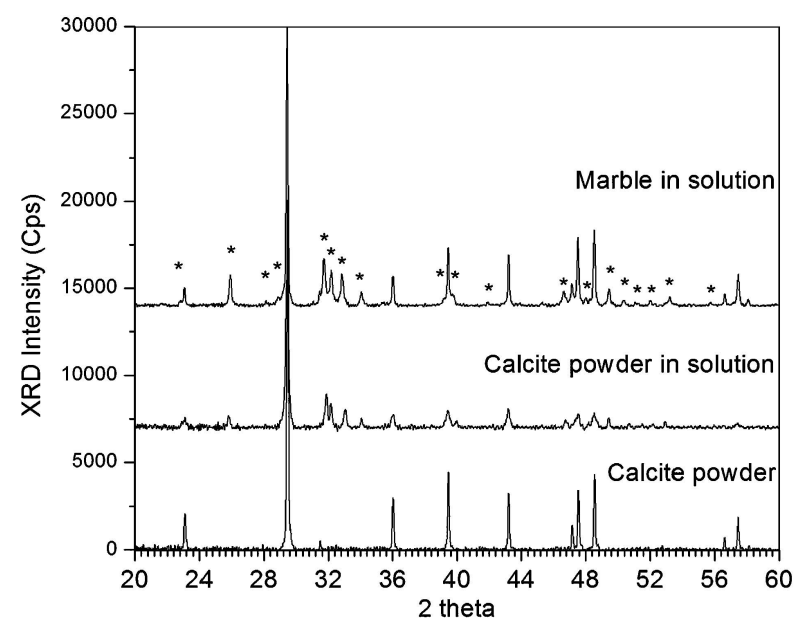

Figure $5 \mathrm{XRD}$ traces of calcite powder and marble cube samples soaked in Na-K-phosphate solution at $60^{\circ} \mathrm{C}$ for $3 \mathrm{~d}$ (bottom trace is that of pure $\mathrm{CaCO}_{3}$ for comparison; * : HA peaks). same XRD pattern with the $\mathrm{CaCO}_{3}$ powders, also exhibited a similar behavior. Percentage of CDHA formed in samples soaked in phosphate solutions at $90^{\circ} \mathrm{C}$ was higher in comparison to those of $60^{\circ} \mathrm{C}$.

The SEM micrographs of Fig. 6 showed, at two different magnifications, first the pristine surfaces of marble cubes (in a and c), and then the apatitic surfaces of those cubes following 3 days of soaking (at $60^{\circ} \mathrm{C}$ ) in the Na-K-phosphate solution of this study. Surface coverage with such characteristic, epitaxially grown CDHA platelets (i.e., the bone mineral) were not just accidental or occasional, and these platelets with a $\mathrm{Ca} / \mathrm{P}$ ratio of around $1.50 \pm 0.03$ (as determined by EDXS studies) were seamlessly and perfectly covering all the available marble surfaces. Samples soaked at $90^{\circ} \mathrm{C}$ had the same morphology and surface coverage. Since this phenomenon is a temperature-activated, time-dependent process, " $37^{\circ} \mathrm{C}-3$ days" treatment was simply not enough to display the $\mathrm{CaCO}_{3}$ to $\mathrm{CDHA}$ conversion.

Hydrothermal conversion [35] of the natural forms (such as coral or nacre) of aragonite samples to hydroxyapatite has previously been studied over the temperature range of 140 to $260^{\circ} \mathrm{C}$, either in aqueous $\left(\mathrm{NH}_{4}\right)_{2} \mathrm{HPO}_{4}$ solutions [36] or in acidic phosphate solutions [37]. Both of these recent studies were not able to produce the characteristic apatitic morphology of interlocking platelets we have reported in Fig. 6. The significant difference in the crystal structures of aragonite (orthorhombic) and calcite (rhombohedral) may have rather a strong role in this, as well as the nature of the phosphate solutions used for achieving this conversion.

Fujita et al. [38] studied the bone bonding behavior of calcite to natural bone in an 8 weeks-long rabbit study, and reported that although there was direct bonding between bone and calcite, they were not able to detect the presence of a surface apatite layer to be formed on the implanted, ex vivo calcite samples. Fujita et al. [38] then concluded that calcite was a biodegradable material that bonded to bone without forming a surface apatite layer. Salingar et al. [39] found that a range of calcium phosphates formed, in vitro, in a timedependent process, when calcite interacted with a dilute carbonated orthophosphate solution. They reported the initial and relatively rapid formation of either an amorphous calcium phosphate phase or crystalline $\mathrm{CaHPO}_{4}$ layer on the calcite surfaces, and its gradual and eventual conversion into hydroxyapatite.

Carbonate sites of the single-phase calcite samples of the present study are believed to be emptied first (via $\mathrm{CO}_{2}+\mathrm{H}_{2} \mathrm{O}=\mathrm{HCO}_{3}^{-}+\mathrm{H}^{+}$) in conjunction with the supply of $\mathrm{HCO}_{3}^{-}$ions into the phosphate solution, at temperatures greater than $37^{\circ} \mathrm{C}$, within the period of soaking times studied here. $\mathrm{PO}_{4}^{3-}$ ions available on the solution side then adsorb themselves at these sites, and start nucleating the carbonated calcium-deficient hydroxyapatite platelets. The in vitro osteogenesis reaction, which starts at the surface then proceeds toward the bulk of the sample with the epitaxial growth of the apatitic platelets. Ohgushi et al. [40] showed that the in vivo bone forming response of $\mathrm{CaCO}_{3}$ was comparable to that of the well-known biactive hydroxyapatite. 


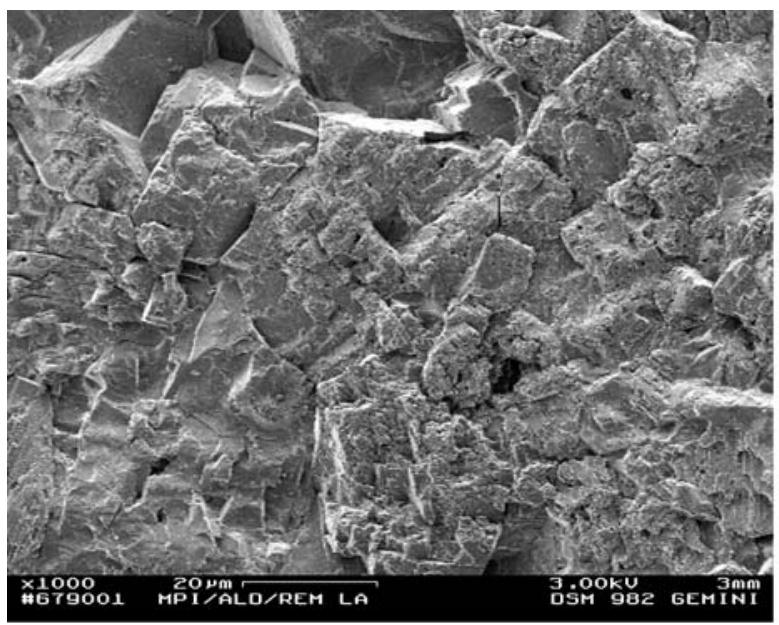

(a)

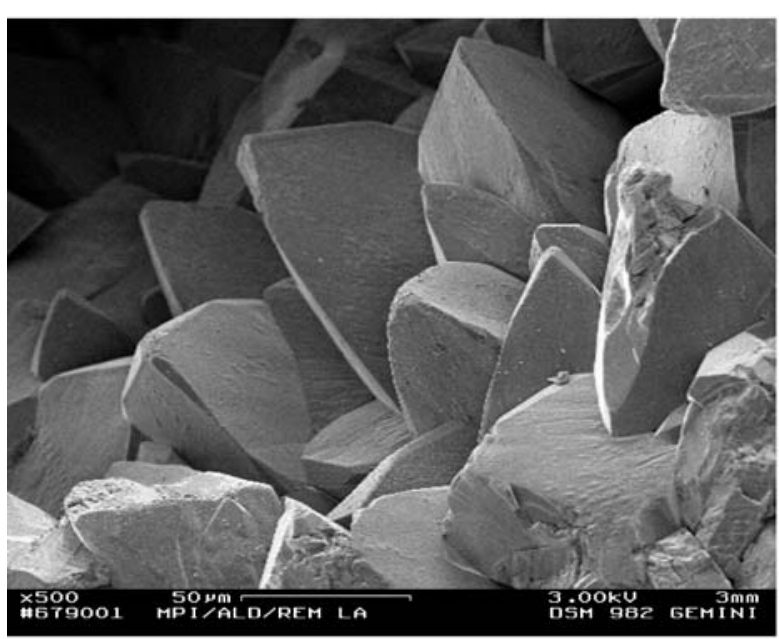

(c)

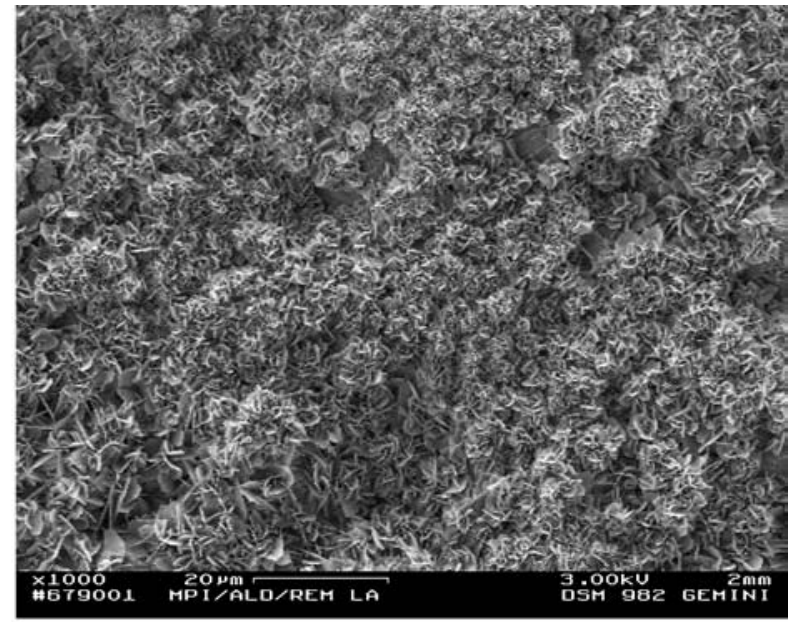

(b)

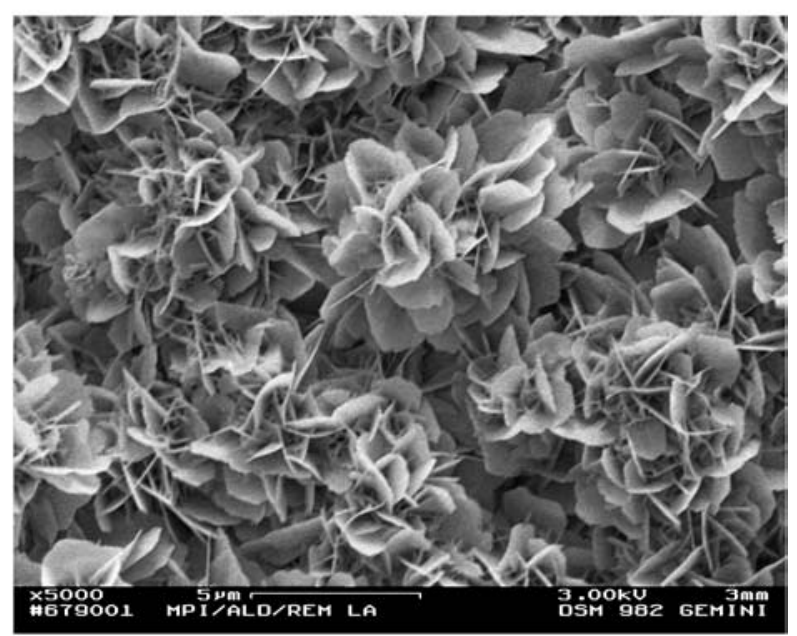

(d)

Figure 6 SEM micrographs of pristine and CDHA-converted surfaces of marble cubes soaked in Na-K-phosphate solution at $60^{\circ} \mathrm{C}$ for 3 days: (a) marble cube (as is), (b) marble cube $\left(60^{\circ} \mathrm{C}\right.$, in PS for $\left.3 \mathrm{~d}\right)$, (c) marble cube (as is), and (d) marble cube $\left(60^{\circ} \mathrm{C}\right.$, in PS for $\left.3 \mathrm{~d}\right)$.

The presence of the enzyme, carbonic anhydrase (CA), in osteoclasts is known [41] to catalyze the above reaction for bicarbonate production. We believe that calcite samples which were first soaked in the Na-K-phosphate solutions of this study, for instance, at $75^{\circ} \mathrm{C}$ for 3 days, would display an improved in vivo bone bonding ability, while possessing an extremely improved mechanical strength.

\section{Conclusions}

Nanosize calcium phosphate powders with a $\mathrm{Ca} / \mathrm{P}$ molar ratio around $1.64( \pm 0.02)$ have been synthesized by a robust technique. A Na-K-phosphate solution of $\mathrm{pH}$ of 7.4 , which is also used as a primary standard reference solution in $\mathrm{pH}$ mesaurements, was used as the phosphor source during the synthesis runs. Poorly crystalline apatitic powders obtained were actually found to be selfhardening calcium phosphate cements. Nanosize powders of this study, which contained small amounts of $\mathrm{Na}$ and $\mathrm{K}$ originating from the solution used during syntheses, were observed to rapidly densify even when calcined at around $850^{\circ} \mathrm{C}$ as a loose powder compact. The same Na-K-containing phosphate solution used in powder synthesis runs was shown to be quite effective in partially converting calcite, $\mathrm{CaCO}_{3}$ (either as powders or marble pieces), into calcium-deficient hydroxyapatite, upon immersion of the samples into that solution in sealed glass bottles kept at $\geq 60^{\circ} \mathrm{C}$ for 3 days. Finding ways of easier conversion of natural marble into a strong bioactive material is promising.

\section{Acknowledgments}

A. C. T. gratefully acknowledges the Max-PlanckInstitut fuer Metallforschung (Stuttgart) for the award of Visiting Professorship extending over the term of February 1999 to February 2001. The authors acknowledge H. Labitzke (FESEM \& EDXS), G. Kaiser (ICPAES), M. Thomas (XRD), H. Kummer (TG/DTA), and W. Koenig (FTIR) for their generous help during various stages of sample characterization.

\section{References}

1. R. G. T. GEESINK, K. DE GROOT and C. P. A. T. K LEIN, Clin. Orthop. Relat. R. 225 (1987) 147.

2. I. ORLy, M. GRegoire, J. Menanteau, M. Heugheb AERT and B. KerEBel, Calcified Tissue Int. 45 (1989) 20. 
3. M. JARCHO, C. H. BOLEN, M. B. THOMAS, J. BOBICK, J. P. KAY and R. H. DOREMUS, J. Mater. Sci. 11 (1976) 2027.

4. M. ASADA, Y. MIURA, A. OSAKA, K. OUKAMI and S. NAKAMURA, ibid. 23 (1988) 3202

5. C. P. A. T. KLEIN, J. M. A. DE BLIECKHOGERWORST, J. G. C. WOLKE and K. DE GROOT, Biomaterials 11 (1990) 509.

6. M. JARCHO, Dent. Clin. N. Am. 30 (1986) 25.

7. A. EBRAHIMPOUR, M. JOHNSSON, C. F. RICHARDSON and G. H. NANCOLlaS, J. Colloid Interf. Sci. 159 (1993) 158.

8. E. HA YEK and H. NEWESELY, Inorg. Synth. 7 (1963) 63.

9. S. LAZIC, J. Cryst. Growth. 147 (1995) 147.

10. A. C. TAS, F. KORKUSUZ, M. TIMUCIN and N. A K K AS, J. Mater. Sci.-Mater. M. 8 (1997) 91.

11. J. Wiltfang, H. A. MERTEN, K. A. SChlegel, S SCHULTZE-MOSGAU, F. R. KLOSS, S. RUPPRECHT and P. KESSLER, J. Biomed. Mater. Res. 63A (2002) 115.

12. F. C. MCLEAN and M. R. URIST, "Bone," 3rd ed. (Univ. of Chicago Press: Chicago, 1968) p. 56.

13. J. D. TER MINE and A. S. POSNER, Arch. Biochem. Biophys. 140 (1970) 307.

14. S. MANN, Biomineralization: Principles and Concepts in Bioinorganic Materials Chemistry (Oxford University Press New York, 2001) p. 11

15. L. L. HENCH and J. WILSON (eds.), "An Introduction to Bioceramics" (World Scientific: Singapore, 1993) p. 142.

16. N. KIVRA K and A. C. TAS, J. Amer. Ceram. Soc. 81 (1998) 2245.

17. D. R. LIDE (ed.), Handbook of Chemistry and Physics, 72nd ed. (CRC Press: Boca Raton, 1991) p. 8.

18. T. KOSHINO, W. KUBOTA and T. MORII, Biomaterials 16 (1995) 125.

19. ICDD PDF: International Centre for Diffraction Data, "Powder Diffraction File" (Newtown Square, PA 19073, USA).

20. W. E. B R OWN and L. C. CHOW, "Dental Restorative Cement Pastes," US Patent 4518 430, May 21, 1985.

21. Y. FUKASE, E. D. EANES, S. TAKAGI, L. C. CHOW and W. E. B ROWN, J. Dent. Res. 69 (1990) 1852.

22. D. D. LEE, C. REY and M. AIOLOVA, "Bioresorbable Ceramic Composites," US Patent 6027 742, February 22, 2000.
23. G. SOCRATES, "Infrared Characteristic Frequencies" (John Wiley \& Sons, New York, 1994)

24. A. C. TAS, Powder Diffr. 16 (2001) 102.

25. K. SUDARS ANAN and R. A. YOUNG, Acta Crystallogr. B 24 (1969) 1534.

26. A. C. TAS, Biomaterials 21 (2000) 1429

27. Z. H. CHENG, A. YASUKAWA, K. KANDORI and T. IS HI K A W A, Langmuir 14 (1998) 6681.

28. M. A. WALTERS, Y. C. LEUNG, N. C BLUMENTHAL, R. Z. LEGEROS and K. A. KONSKER, J. Inorg. Biochem. 39 (1990) 193.

29. S. J. GADAlETA, E. P. PASCHALis, F. BETTS, R. MENDELSOHN and A. L. BOS KEY, Calcified Tissue Int. 58 (1996) 9.

30. J. KAPOLOS and P. G. KOUTS OU K OS, Langmuir 15 (1999) 6557.

31. S. V. DOROZH Kin, J. Colloid Interf. Sci. 191 (1997) 489.

32. I. MANJUBAla and M. SIVAKUMAR, Mater. Chem. Phys. 71 (2001) 272.

33. R. A. NYQUist, C. L. PUTZIG and M. A. LEUGEERS, "Handbook of Infrared and Raman Spectra of Inorganic Compounds and Organic Salts" (Academic Press, San Diego, 1997).

34. F. PETERS and M. EPPLE, J. Chem. Soc. Dalton. 24 (2001) 3585 .

35. D. M. ROY, "Porous Biomaterials and Method of Making Same," US Patent, 3929 971, December 30, 1975

36. C. M. ZAREMBA, D. E. MORSE, S. MANN, P. K. HANSMA and G. D. STUCKY, Chem. Mater. 10 (1998) 3813

37. S. JINAWATH, D. POLCHAI and M. YOSHIMURA, Mater. Sci. Eng. 22C (2002) 35.

38. Y. FUJITA, T. YAMAMURO, T. NAKAMURA, S KOTANI, C. OHTSUKI and T. KOKUBO, J. Biomed. Mater. Res. 25 (1991) 991.

39. Y. SAlingAR and M. KOCHVA, Soil Sci. Soc. Amer. J. 58 (1994) 1628.

40. H. OHgushi, M. OKumura, T. yoshikawa, K ONIOUE and E. C. SHORS, J. Biomed. Mater. Res. 26 (1992) 885.

41. G. GUILlemin, J. L. PATAT, J. FOURNiE and M. CHET AIL, ibid. 21 (1987) 557.

Received 14 November 2003 and accepted 23 June 2004 